\title{
Complex Origins and Multiple Ages of Mantle Zircon Megacrysts from Canadian and South African Kimberlites
}

\author{
LeCheminant, A.N. ${ }^{1}$, Heaman, L.M. ${ }^{2}$, Kretschmar, U. ${ }^{3}$, and LeCouteur, P.C. ${ }^{4}$ \\ ${ }^{1}$ Geological Survey of Canada, 601 Booth Street, Ottawa, Ontario, K1A 0E8, Canada \\ ${ }^{2}$ Dept. of Earth and Atmospheric Sciences, University of Alberta, Edmonton, Alberta, T6G 2E3, Canada \\ ${ }^{3}$ Kretschmar International Geoscience Corp., 408 Bay Street, Orillia, Ontario, L3V 3X4, Canada \\ ${ }^{4}$ Micron Geological Ltd., 4900 Skyline Drive, N. Vancouver, British Columbia, V7R 3J3, Canada
}

Mantle-derived zircons from the Drybones Bay kimberlite, Slave craton, Canada and the Kaalvallei and Leicester kimberlites, Kaapvaal craton, South Africa have diverse multi-stage origins. SEM backscattered electron (BSE) and cathodoluminescence (CL) imaging when combined with U-Pb age determinations provide precise information on the growth, fragmentation and ascent histories of individual zircon megacrysts. Sharply defined oscillatory and sector zoning patterns are preserved in zircons from all three kimberlites and reveal that most megacrysts have complex growth histories.

The Drybones Bay kimberlite was discovered in 1994, as a result of work by David Smith of Yellowknife. The kimberlite is ca. $900 \mathrm{~m}$ long by $400 \mathrm{~m}$ wide, and consists of three, closely related, but separate intrusions, all diamond-bearing. Indicater minerals and xenoliths indicate the intrusions sampled upper mantle peridotitic and eclogitic sources. Crustal xenoliths include numerous granitoid rocks, with minor gabbro and lower crustal granulites. Abundant zircon megacrysts have been identified in drill core, dense media separation concentrates and caustic fusion residues from the kimberlites. Many zircon grains are homogeneous in both BSE and CL images. Others display a diffuse CL response related to fracture sets or grain boundaries and some have weakly defined, irregular zoning patterns. A few grains have sharply defined, fine scale oscillatory zones. Some zircon and ilmenite grains have a two-stage history of early crystal growth followed by deformation and recrystallization forming polygonal arrays of newly grown zircon and ilmenite along subgrain boundaries. Fragmentation followed by reactions with fluids or kimberlitic magmas resulted in desilicification of zircon along grain margins and internal fracture sets to form a porous intergrowth of $\mathrm{ZrO}_{2}$ (baddeleyite) at a sharp reaction front. Coarsening outwards baddeleyite-rich rims up to 40 $\mu \mathrm{m}$ thick are associated with apatite, phlogopite, serpentine and chalcopyrite.

Individual mantle zircons recovered from caustic fusion residues have been dated from kimberlite intersected in two different drill holes at Drybones Bay. The zircons have low U (4.0-9.9 ppm) and Th (0.9-13.6 ppm) contents, typical of mantle zircon, and generally show some degree of discordance (Davis, 1977). Six individual grains from hole 95-7 define a discordia line with an upper intercept age of ca. $485 \mathrm{Ma}$. Five zircon grains from hole $95-8$ show less discordance and have ${ }^{206} \mathrm{~Pb} /{ }^{238} \mathrm{U}$ ages between $437-467 \mathrm{Ma}$

The Leicester East and West pipes, $40 \mathrm{~km}$ north of Kimberley, South Africa, have supported sporadic, small-scale diamond mining for about 100 years. The east pipe has three main phases; the most abundant is a diatreme facies tuffisitic breccia classified as a Group 1 monticellite kimberlite. The next most abundant phase is a marginal shale-rich kimberlitic breccia; micaceous, fragment-poor hypabyssal kimberlite intruded the two breccias. Davis (1977) reported a U-Pb age of $93.6 \mathrm{Ma}$ for a zircon from Leicester containing $18.5 \mathrm{ppm}$ U. Zircons ranging in size from 4 to $10 \mathrm{~mm}$ were recovered from pan concentrates from Leicester East kimberlites during bulk sampling in the period 
1992-1994. Other minerals present in the concentrates include chrome diopside, ilmenite, chromite, corundum and three garnet populations (peridotitic, eclogitic and megacrystic suites).

Leicester zircons range in colour from pale to dark amber and display yellow-orange fluorescence in short wavelength UV light. Most have frosted or white baddeleyite-coated surfaces and several are partly coated by black zirconolite. BSE images indicate baddeleyite-rich reaction rims up to $50 \mu \mathrm{m}$ wide contain crystals oriented perpendicular to the zircon surface. In addition to coarsening outward arrays of baddeleyite crystals, the rims contain abundant clinopyroxene and minor apatite and phlogopite. CL images show the zircon grains are fractured pieces of larger crystals; sector and oscillatory zones within crystals are irregularly truncated by baddeleyite rims. One zircon fragment has a well defined oscillatory zoning pattern throughout, visible as sharply bounded zones about 50$100 \mu \mathrm{m}$ wide. Uniform groups of up to 10 rhythmic zones are separated by smaller groups of brightCL zones. The event that broke up the original crystal left a shattered zircon sliver still attached. This sliver contains a conjugate array of fractures along which zircon is variably replaced by baddeleyite and then sealed by clinopyroxene: Another zircon grain has a homogeneous dark-CL core and a complexly zoned rim characterized by well defined sector zoning and fine-scale oscillatory zoning. During growth, a calcite grain $(90 \times 250 \mu \mathrm{m})$ was incorporated onto the surface, causing a break in the zoning pattern. Subsequently, the calcite inclusion was locally modified along its margins by a reaction involving zircon breakdown to form spongy baddeleyite plus clinopyroxene and an unidentified $\mathrm{Na}$,K-bearing zirconosilicate.

The Kaalvallei kimberlite is located $10 \mathrm{~km}$ southeast of Welkom, S. Africa. The host kimberlite is a circular pipe ca. $160 \mathrm{~m}$ in diameter. High quality diamonds were recovered from open pit and underground workings. Large mantle zircon grains, up to $2 \mathrm{~cm}$ in size, were also recovered and range in colour from pale pink to various shades of amber. A few display sharply bounded colour domains from amber to near colourless. Many grains have a partial or complete grey baddeleyite coating. Other minerals present in the concentrate include megacrystic and eclogitic garnets, chrome diopside, ilmenite, chromite, and pyrite. Both peridotite and diamond-bearing eclogite xenoliths have been recovered.

CL images of Kaalvallei zircons show that the amber to near colourless domains can record either a two-stage history of crystal growth, from a homogeneous core to a sector zoned rim, or the colour change defines a sector zone boundary. Sector zoned crystals, originally $>5 \mathrm{~cm}$ in length, were fragmented prior to development of baddeleyite rims. In one grain, the dark-CL sector contains evenly spaced, oscillatory zones down to a few microns wide, with as many as fifty minor oscillations separating distinctive couplets that may record competing diffusion controlled processes at the surface of the growing crystal. The zircon grains contain large $(100-400 \mu \mathrm{m})$, rounded calcite and ilmenite inclusions. Locally, baddeleyite and clinopyroxene form discontinuous reaction zones along calcite-zircon contacts. Ilmenite inclusions (up to $1 \mathrm{~mm}$ in size) have a partial rim of calcite, zirconolite, a $\mathrm{Na}-\mathrm{Ca}$ zirconosilicate, Ti-rich baddeleyite and minor phlogopite. Internally, many zircon grains contain fracture sets characterized by a dendritic network of hollow channelways with euhedral baddeleyite grains in larger cavities. Similar features are present in both Leicester and Drybones Bay zircons. CL images indicate that limited diffusion-controlled alteration occurs along some fractures and can be used to define fracture sets of different age. The outer baddeleyite reaction rim is up to $375 \mu \mathrm{m}$ thick and consists of coarsening outwards baddeleyite crystals oriented perpendicular to the contact, separated by calcite, apatite and clinopyroxene - the largest baddeleyite needles are about $120 \times 25 \mu \mathrm{m}$ in size. One $7 \times 4 \mathrm{~mm}$ euhedral zircon grain has been identified. It has a 
two-stage growth history and an unusual, thin baddeleyite rim associated with development of subrounded flat bottom pits ca. $150 \mu \mathrm{m}$ in diameter. Baddeleyite in these pits form a radial array of crystals. Penetration of the baddeleyite reaction front into the zircon crystal is to some extent controlled by the compositional zoning as the reaction front is observed to stop at specific chemical boundaries within the crystal. Baddeleyite crystals show bright luminescence in $\mathrm{Cl}$ images of Kaalvallei zircons, and are brighter than zircon. In contrast, baddeleyite associated with Drybones Bay and Leicester zircons are only weakly luminescent, and are darker than zircon.

Mantle zircons are less susceptible to chemical and isotopic disturbance than most other minerals transported in kimberlites. CL images of zircons are sensitive to variations in rare-earth elements (REE) and recent studies of REE diffusion in zircon indicates they are essentially immobile under most geologic conditions (Cherniak et al., 1997). Preservation of sharply defined oscillatory and sector zones in mantle kimberlites from Drybones Bay, Leicester and Kaalvallei suggest that primary trace element zoning patterns and zircon growth histories are preserved in mantle zircons despite the fact that they resided for some time under high-temperature mantle conditions and were subjected to subsequent deformation-controlled recrystallization, fragmentation, alteration and desilicification prior to transport in the kimberlite magma.

$\mathrm{U}-\mathrm{Pb}$ results for Drybones Bay zircon fragments indicate that multiple crystallization events occurred over at least a $40 \mathrm{~m} . \mathrm{y}$ period between 485 and $440 \mathrm{Ma}$. Specific ages are not yet linked to multistage histories identified in CL and BSE images, but new determinations are targeted to provide ages for each event. Previously, mantle zircon $\mathrm{U}-\mathrm{Pb}$ ages were interpreted to establish the timing of kimberlite emplacement based partly on the assumption that U-Pb systematics are continuously reset under upper mantle conditions prior to transport to the surface (Davis et al., 1980). SHRIMP U-Pb ion-probe results for some mantle zircon grains demonstrate that old pre-eruption ages can occasionally be preserved (Kinny et al., 1989; Kinny and Meyer, 1994). The $>40$ m.y. range of ages from Drybones Bay zircons and the sharply defined zoning patterns in zircon fragments from Canadian and South African kimberlites could reflect the presence of a pre-eruption mantle zircon component in these pipes. However, the concordant $\mathrm{U}-\mathrm{Pb}$ zircon results in one sample indicate that there has been negligible post-440 Ma Pb-loss, supporting a ca. $440 \mathrm{Ma}$ emplacement age for the Drybones Bay kimberlite. Mantle zircon grains and the baddeleyite rims that armour them are unique in their ability to retain information about processes within the deep lithosphere and uppermost asthenosphere. Mantle zircon grains investigated from Drybones Bay, Leicester and Kaalvallei preserve detailed information about the timing and nature of mantle processes that modified the mantle beneath the Slave and Kaapvaal cratons prior to kimberlite emplacement.

\section{References}

Cherniak, D.J., Hanchar, J.M., Watson, E.B., 1997, Rare-earth diffusion in zircon: Chemical Geology, 134, p. $289-301$.

Davis, G.L., 1977, The ages and uranium contents of zircons from kimberlites and associated rocks: Carnegie Institution, Geophysical Laboratory, Washington, Yearbook 76, p. 631-635.

Davis, G.L., Sobolev, N.V., Khar'kiv, A.D., 1980, New data on the age of Yakutian kimberlites obtained by the uranium-lead method on zircons: Doklady Akad Nauk SSSR, 254, p. 53-57.

Kinny, P.D., Compston, W., Bristow, J.W., Williams, I.S., 1989, Archean mantle xenocrysts in a Permian kimberlite: two generations of kimberlitic zircon in Jwaneng DK2, southern Botswana: In: Ross, J. (Ed.), Kimberlites and Related Rocks. Geological Society of Australia Special Publication 14, p. 833-842.

Kinny, P.D., Meyer, H.O.A., 1994, Zircons from the mantle: a new way to date old diamonds: Journal of Geology, 102, p. $475-481$. 